Матеріали Всеукраїнської науково-практичної конференчії «Актуальні питання діагностики, лікування, раціональної фармакотерапії, диспансеризації та реабілітації в практичі сімейного лікаря"

DOI

\title{
ОСОБЛИВОСТІ МІНЕРАЛЬНОÏ ЩІЛЬНОСТІ КІСТКОВОЇ ТКАНИНИ У ХВОРИХ НА КОМОРБІДНУ ПАТОЛОГІЮ ОРГАНІВ ТРАВЛЕННЯ ОСІБ ЖІНОЧОЇ СТАТІ
}

\author{
๑Т. В. Бойко, Г. В. Лихацька, В. О. Лихацька, В. І. Бойко
}

ДВНЗ «Тернопільський державний медичний університет імені І. Я. Горбачевського МОЗ України»

Вступ. В останні роки проблема остеопорозу (ОП) набула особливого звучання внаслідок двох тісно пов'язаних демографічних процесів: різкого збільшення в популяції старих людей і, відповідно, кількості жінок у постменопаузі. Приблизно в кожної третьої жінки після 65 років трапляється один остеопоротичний перелом. Переломи стегнової кістки приводять до зменшення тривалості життя на 12-15 років. Хронічні запальні захворювання гастродуоденопанкреатичної зони і печінки супроводжуються зниженням абсорбції мінералів і вітаміну D в кишечнику, внаслідок чого знижується мінеральна щільність кісткової тканини (МЩКТ), що часто призводить до інвалідизації хворих.

Мета дослідження - вивчити особливості МЩКТ у жінок з коморбідною патологією органів травлення залежно від фертильної функції та тривалості захворювання.

Матеріал і методи дослідження. Нами було обстежено 33 жінки, хворих на хронічний гастродуоденіт у поєднанні з хронічним панкреатитом на тлі хронічних гепатитів. 3 них 15 (45,5\%) були в постменопаузі, та 18 (55,5 \%) - зі збереженою фертильною функцією.

Для верифікації діагнозу використовували широкий спектр клінічних і лабораторно-інструментальних обстежень (загальний та біохімічний аналізи крові, сечі, копрограма, імуноферментний аналіз крові на виявлення маркерів вірусних гепатитів та антитіл до Нр, у частини хворих ПЛР на виявлення Нр і вірусів гепатитів В, С, інтрагастральна рН-метрія, ЕГДФС з гістологічним та цитологічним дослідженням, ультразвукове дослідження органів черевної порожнини, денситометричне обстеження поперекового відділу хребта та проксимального відділу правої стегнової кістки). 3 дослідження виключали хворих із тяжкою супутньою патологією, яка 6 могла спричинити вірогідні зміни кісткової тканини.

Результати досліджень. Проведені обстеження показали, що у 26 (78,8 \%) обстежуваних був остеодефіцит різного ступеня, у тому числі ОП - у 7 (21,2 \%). Причому відмічалися достовірно нижчі показники МЩКТ у жінок в постменопаузі (Т, од. ст. відхилення - $(-2,75 \pm 0,22))$, порівняно з жінками зі збереженою оваріально-менструальною функці$\epsilon ю$ (Т, од. ст. відхилення $(-1,66 \pm 0,27),(p<0,01)$. Відмічалося поглиблення остеодефіциту при збільшенні тривалості захворювання. Так, МЩКТ була достовірно нижчою у групі обстежуваних з тривалістю захворювання понад 10 років $(p<0,01)$.

Висновки. 1. Частота виникнення остеодефіциту у хворих на коморбідну патологію органів травлення зростає у жінок постменопаузального періоду та із збільшенням тривалості захворювання.

2. Наявність коморбідної патології органів травлення та менопауза $\epsilon$ важливими детермінантами, які визначають глибину остеодефіциту, поширеність і швидкість розвитку остеопорозу, що вимагає періодичного обстеження жінок та лікувально-профілактичних заходів даної категорії з метою запобігання остеопорозу і його ускладненням.

Перспективи подальших досліджень полягають у вивченні мінеральної щільності кісткової тканини залежно від статі. 